\title{
Menjadi Muslim di Negara Multikultural: Dinamika, Tantangan dan Strategi dalam Perspektif Fikih Multikultural
}

\author{
Masnun Tahir
}

\begin{abstract}
Being A Muslim in a Multicultural Country: Dynamics, Challenges and Strategies in Multicultural Fiqh Perspectives. Indonesian Islam is a unique one, pluralist and multiculturalist as Nahdlatul Ulama Islam, Muhammadiyah Islam, Shiah Islam, Sunni Islam and much more which has diverse consequences for its followers. As matter of fact, the diversity continues to face challenges. An Accusation against moderate and multiculturalism through violence is perpetrated by individual actors, mass organization and the most authoritatve institution that should be the guarantor of religious moderatism within the framework of Indonesian-ness. At the extreme level, the resistance is manifested in a series of intolerant actions such as expulsion. This paper aimed to present how life strategy in the nuances of multicultural from the perspective of Islamic law. The idea of fiqh that is sensitive to multiculturalism becomes important for Muslims in Indonesia to have a diversity of perspectives in the daily basis.
\end{abstract}

Keywords: Islam, multicultural, multicultural fiqh

Abstrak: Menjadi Muslim di Negara Multikultural: Dinamika, Tantangan dan Strategi dalam Perspektif Fikih Multikultural. Islam Indonesia adalah unik, pluralis dan multikulturalis sebagai Islam Nahdlatul Ulama, Islam Muhammadiyah, Islam Syiah, Islam Sunni dan banyak lagi yang memiliki konsekuensi beragam bagi para pengikutnya. Faktanya, keberagaman terus menghadapi tantangan. Tuduhan terhadap moderat dan multikulturalisme melalui kekerasan dilakukan oleh aktor individu, organisasi massa, dan institusi paling otoritatif yang seharusnya menjadi penjamin moderatisme agama dalam kerangka keindonesiaan. Pada level ekstrem, perlawanan dimanifestasikan dalam serangkaian tindakan intoleran seperti pengusiran. Tulisan ini bertujuan untuk mempresentasikan bagaimana strategi kehidupan dalam nuansa multikultural dari perspektif hukum Islam. Gagasan fikih yang peka terhadap multikulturalisme menjadi penting bagi umat Islam di Indonesia untuk memiliki keragaman perspektif dalam kehidupan sehari-hari.

Kata Kunci: Islam, multikultural, fikih multikulturalisme

Universitas Islam Negeri Mataram

Jl. Pendidikan No. 35, Dasan Agung Baru, Selaparang, Kota Mataram, Nusa Tenggara Barat 83125

E-mail: masnun_tahir@yahoo.com 


\section{Pendahuluan}

Kemajemukan Agama-agama (pluralisme) dan budaya (multikulturalisme) adalah tantangan yang dihadapi pemikiran dan kehidupan umat manusia dewasa ini. Pertanyaannya adalah apakah kemajemukan itu bersifat alamiyah?. Bagaimana menyikapi kemajemukan ini?.

Terlepas dari pro dan kontra yang ada, multikulturalisme merupakan fakta yang tergelar di hadapan, sebab masyarakat Indonesia adalah masyarakat yang heterogen dan multikultur dengan beragam etnis dan budaya. Dalam kondisi demikian, yang dibutuhkan bukanlah monokulturalisme tetapi multikulturalisme, ${ }^{1}$ bukan pembauran tetapi pembaruan, bukan ko-eksistensi tetapi pro-eksistensi, bukan sikap eksklusif melainkan sikap inklusif, bukan bukan separasi tetapi interaksi. Bukan juga kemajemukan demi kemajemukan, atau kemajemukan sekedar warna-warni, tetapi kemajemukan yang dibangun di atas landasan multi-

${ }^{1}$ Terkait pembahasan tentang multikultural bisa dilihat pada karya Parsudi Suparlan. "Menuju Masyarakat Indonesia yang Multikultural." Antropologi Indonesia (2014). Ruslan Ibrahim. "Pendidikan Multikultural: Upaya Meminimalisir Konflik dalam Era Pluralitas Agama." El Tarbawi 1, no. 1 (2008): h. 115-127. Tatang M Amirin. "Implementasi Pendekatan Pendidikan Multikultural Kontekstual Berbasis Kearifan Lokal di Indonesia." Jurnal Pembangunan Pendidikan: Fondasi dan Aplikasi 1, no. 1 (2012). Andik Wahyun Muqoyyidin. "Membangun Kesadaran Inklusif-Multikultural untuk Deradikalisasi Pendidikan Islam." Jurnal Pendidikan Islam 2, no. 1 (2012). Sri Ambarwangi, dan S. Suharto. "Pendidikan Multikultural di Sekolah Melalui Pendidikan Seni Tradisi." Harmonia: Journal Of Arts Research And Education 13, no. 1 (2013). Nurul Zuriah. "Model Pengembangan Pendidikan Kewarganegaraan Multikultural Berbasis Kearifan Lokal dalam Fenomena Sosial Pasca Reformasi di Perguruan Tinggi." Jurnal Penelitian Pendidikan 12, no. 2 (2011): h. 63-72. Suhadi Cholil. Resonansi Dialog Agama dan Budaya: dari Kebebasan Beragama, Pendidikan Multikultural, Sampai RUU Anti Pornografi. Center for Religious \& Cross-Cultural Studies, Sekolah Pascasarjana, Universitas Gadjah Mada, 2008. Edi Susanto Edi Susanto. "Pendidikan Agama Berbasis Multikultural (Upaya Strategis Menghindari Radikalisme)." Jurnal Karsa (Terakreditasi no. 80/DIKTI/Kep/2012) 9, no. 1 (2012): h. 782-789. Gina Lestari. "Bhinnekha Tunggal Ika: Khasanah Multikultural Indonesia di Tengah Kehidupan SARA." Jurnal Ilmiah Pendidikan Pancasila dan Kewarganegaraan 28, no. 1 (2016). Ketut Gunawan, dan Yohanes Rante. "Manajemen Konflik Atasi Dampak Masyarakat Multikultural di Indonesia." Jurnal Mitra Ekonomi dan Manajemen Bisnis 2, no. 2 (2011): h. 212224. Husniyatus Salamah Zainiyati. "Pendidikan Multikultural: Upaya Membangun Keberagamaan Inklusif di Sekolah." Islamica: Jurnal Studi Keislaman 1, no. 2 (2007): h. 135-145. Sitti Mania. "Implementasi Pendidikan Multikultural dalam Pembelajaran." Lentera Pendidikan: Jurnal Ilmu Tarbiyah dan Keguruan 13, no. 1 (2010): h. 78-91. Rosita Endang Kusmaryani. "Pendidikan Multikultural Sebagai Alternatif Penanaman Nilai Moral dalam Keberagaman." Paradigma 1, no. 02 (2011). Syamsul Ma'arif. "Transformative Learning dalam Membangun Pesantren Berbasis Multikultural." Jurnal Pembangunan Pendidikan: Fondasi dan Aplikasi 1, no. 1 (2012). I Nyoman Nurjaya. "Pembangunan Hukum Negara dalam Masyarakat Multikultural: Perspektif Hukum Progresif." Progressive Law Journal (Jurnal Hukum Progresif) 3, no. 2 (2011): h. 16. 
kutluralisme yang partisipatorik dan emansipatorik. Dengan bahasa lain, keragaman seharusnya menjadi alat integrasi bangsa apabila sejak dini kesadaran multikultural telah mapan dan menjadi bagian dari komitmen bersama dalam kehidupan berbangsa dan bernegara. ${ }^{2}$

Islam Indonesia adalah Islam yang sangat unik, pluralis dan multikulturalis seperti Islam NU, Islam Muhammadiyah, Islam Syiah, Islam sunny dan lainnya yang mempunyai konsekuensi keberagamaan bagi para pengikutnya. Realitas Indonesia yang multikultural tersebut antara lain terjadi di Pulau Lombok yang memiliki keberagaman unik dengan suku dan budaya pluralis.

Sebanyak 204 juta muslim dilahirkan dan tinggal di negeri ini, membentukan 12,5 persen dari total 1,6 miliar pemeluk Islam di dunia. Sebuah angka yang semestinya cukup signifikan dalam menggerakkan pendulum peradaban Islam dunia. ${ }^{3}$ Tetapi, kebesaran sebagai bangsa tidak cukup pada pengetahuan tentang pluralitas ini dan kemudian berbuat sendiri-sendiri. Kebesaran yang sesungguhnya terletak pada bagaimana membangun kesadaran dan mampu hidup bersama di dalamnya, mengalami perbedaan dalam kesamaan (to experienced difference in equality), serta bersedia bekerja sama untuk kemaslahatan bersama. ${ }^{4}$

Keberagaman dan kompleksitas keberagamaan Islam seperti itu bukan hanya dapat dijumpai di Lombok sebagai fokus pembahasan artikel ini, tetapi juga di wilayah lain di Indonesia. Realitas ini di luar pulau Lombok, sesungguhnya telah banyak dideskripsikan para sarjana, seperti Adam Schwarz menyatakan:

...dengan hampir 90\% warganya memeluk agama Islam, Indonesia adalah negara dengan proporsi umat Islam terbesar di dunia. Ini sebuah contoh yang baik tentang bagaimana jumlah bisa menyesatkan, karena Islam di Indonesia adalah sebuah keyakinan yang heterogen. ${ }^{5}$

2 Sultan Syahrir, "Mulitkulturalisme: Perspektif Normatif dan Historis", Jurnal Analisis 13, no. 2, (2013), h. 294-295.

${ }^{3}$ Masdar Hilmy, Jalan Demokrasi Kita, Etika Politik, Rasionalitas dan Kesalehan Publik (Malang: Intrans Publishing Malang, 2017).

${ }^{4}$ Muhamad Ali, Teologi Pluralis-Mutikulturalis, Menghargai Kemajemukan Menjalin Kebersamaan (Jakarta: Kompas, 2003), h. 94.

${ }^{5}$ Adam Schwarz, A Nation in Waiting Indonesian in the 1990 (Australia: Allen \& Unwin Pty Ltd, 1994), h. 163. 
Sementara itu, Dijk mengatakan:

...ketika Islam disebarkan di Indonesia, Islam dihadapkan oleh masyarakatmasyarakat yang sudah mapan serta memiliki struktur yang sudah jelas dan kepercayaan-kepercayaan yang mengakar kuat. Islam menjadi agama resmi masyarakat-masyarakat tersebut, tetapi terbukti tidak gampang untuk menggantikan kepercayaan dan adat istiadat lama. ${ }^{6}$

Demikian juga Ricklefs menggambarkan hal yang serupa mengenai dinamika dan watak subkultural Islam Indonesia:

Jika saja ada catatan sejarah yang lebih memuaskan, maka orang tak akan ragu-ragu menarik perbedaan yang lebih kompleks dan lebih subtil antar berbagai daerah di Indonesia dan berbagai periode sejarahnya. Tetapi, bukti tidak utuh tentang permulaan Islamisasi saja sudah cukup untuk menunjukkan bahwa Islam di Indonesia sejak dari mulanya sudah berinteraksi dengan konteks sosial setempat yang akhirnya membuahkan hasil sosial politik dan religius yang berbeda-beda. Kesatuan Iman Islam yang ditekankan oleh para pengikutnya terlihat jelas di Indonesia, tetapi jelas juga terlihat keanekaragaman sosial yang sudah berbuat banyak memberikan dinamisme kepada sejarah Islam Indonesia. Dinamisme itulah ciri khas kedua sejarah itu. ${ }^{7}$

Sebelum Islam masuk ke wilayah tertentu di Indonesia, berbagai macam adat kuno dan kepercayaan lokal banyak dipraktikkan dan sangat menyatu dengan struktur sosial setempat. Ketika Islam datang, ia dihadapkan dengan nilai-nilai lama, beberapa di antaranya mengandung unsur-unsur Hindu dan Buddha. Alih-alih membersihkan sepenuhnya anasir non-Islami, Islam justeru mengakomodir unsur-unsur itu dan pada akhirnya disinkretisasi ke dalam tradisi lokal. Keberadaan orang Islam abangan sinkretik di Jawa dan penganut Wetu Telu Sasak di Pulau Lombok merupakan bukti Islam dipraktikkan berdampingan dengan kepercayaan-kepercayaan lokal yang mengandung anasir non-Islam.

Perbedaan perspektif dan pemahaman dalam menyerap dan menjalankan ajaran-ajaran Islam serta akomodasi agama ini ke dalam struktur lokal yang spesifik telah menyumbang pluralitas dam parokialisasi Islam

${ }^{6}$ V.C. Dijk, Rebellion Under the Banner of Islam (The Hague: Martinus Nijhoff, 1981), h. 7.

${ }^{7}$ M.C. Ricklefs, Sejarah Indonesia Modern (Yogyakarta: Gadjah Mada University Press, 1991), h. 4-5. 
di Indonesia. Soebardi menggambarkan pluralitas subkultur Islam di Indonesia:

Realitas kehidupan Islam sangat pluralistik. Seseorang bisa menjumpai berbagai perbedaan cara orang Islam menerima dan menjalankan ajaran Islam. Kelompok-kelompok ortodoks menjalankan kewajiban-kewajiban agama dengan penuh ketaatan. Di pihak lain, ada banyak sekali orang menyebut dirinya Islam, tetapi pengetahuan tentang hukum dan ajarannya sangat dangkal dan tidak sempurna serta tidak bertindak-tanduk menurut petunjuk agama mereka dalam kehidupan sehari-hari. Bisa ditambahkan di sini bahwa ada banyak sekali anasir peribadatan yang berasal dari zaman pra-Islam. ${ }^{8}$

\section{Kasus Lombok Sebagai Komunitas Multikultural}

Pluralitas masyarakat Indonesia, tercermin dari berbagai ragam budaya dan agama yang dipeluk termasuk beraneka-ragam suku, seperti Suku Melayu, Suku Batak, Suku Jawa, Suku Sunda, Suku Madura, Suku Bugis, Suku Dayak, dan sebagainya. Kondisi demikian ini memungkinkan mudah terjadinya konflik. Munculnya bermacam-macam kasus kerusuhan, disinyalir karena tidak adanya pemahaman yang cukup terhadap pluralitas budaya dan agama yang berperspektif multikultural. Sebaliknya, pemahaman dan penafsiran agama yang bersifat monolitik cenderung memunculkan klaim kebenaran (truth claim). Pandangan monolitik cenderung memunculkan sikap tidak memberi ruang bagi pemeluk agama yang berbeda untuk mengakui kebenaran agama dan budaya lain, termasuk local wisdom (kearifan lokal). ${ }^{?}$

Di Lombok hidup dan berkembang beberapa agama, budaya dan keyakinan. Sebagai masyarakat multikultural, orang-orang Lombok tersegmentasi atas kelompok-kelompok penganut agama yang berbeda yaitu Islam, Hindu, Kristen, Budha, Katolik dan bahkan keyakinan lokal seperti Wetu Telu.

Dengan demikian, perbedaan ortodoksi dan ortopraksi dalam praktik

${ }^{8}$ Erni Budiwanti, Islam Sasak; Wetu Telu Versus Waktu Lima (Yogyakarta: LKiS, 2000), h. 88.

${ }^{9}$ Ahmad Sodli, "Revitalisasi Kearifan Lokal dalam Masyarakat Multikultural di Kecamatan Lingsar, Lombok Barat, NTB", Jurnal Analisa 17, No. 2 (Juli-Desember, 2010), h. 188 
keberagaman Islam menjadi indikasi bahwa karakteristik Islam di Lombok di samping bersifat plural juga kompleks. Pluralitas dan kompleksitas keberagamaan Islam semacam itu di Lombok hingga kini masih sangat menonjol, meskipun misi modernisasi dakwah Islamiyah gencar dilakukan terhadap masyarakat Sasak sebagaimana dinyatakan oleh Tuan Guru Zainal Arifin Munir sebagai berikut:

Meskipun upaya pembaruan Islam di Lombok sudah cukup lama dan gencar dilakukan oleh para Tuan Guru selaku senior-senior kami, seperti TGH. M. Soleh Chambali, TGH. Zainuddin Abdul Madjid dari Lombok Timur, TGH. Makmun dari Praya, Lombok Tengah, TGH. Japar dan TGH. Abdul Hakim dari Lombok Barat, namun keragaman praktik-praktik keagamaan orang Sasak di Lombok hingga kini masih cukup menonjol. Bukti-bukti keragaman dan perbedaan itu, bukan hanya tampak pada praktik Islam Wetu Telu dengan Waktu Lima, tetapi juga di antara kelompok Waktu Lima sendiri, seperti antara Muhammadiyah dan Wahabiah dengan NU ataupun NW, dan bahkan di antara kelompok NW sendiri, juga belum menunjukkan keseragaman; khususnya pada praktik membawa sesaji ke kuburan pada hari-hari raya Islam, dan pemujaan terhadap makhluk gaib atau roh untuk tujuan tertentu, sekalipun praktik ini sudah lama dilarang dilakukan oleh umat Islam di pulau Lombok. ${ }^{10}$

Deskripsi mengenai keragaman realitas umat Islam, baik di Lombok maupun di luar Lombok, mengidentifikasikan bahwa di seluruh wilayah kepulauan ini pemahaman ajaran-ajaran Islam sangat bervariasi dan hal tersebut mengakibatkan munculnya berbagai perbedaan dalam interpretasi dan praktik beragama. Penyebaran agama Islam yang tidak merata dan pelestarian kepercayaan-kepercayaan lokal dan zaman sebelum masuknya Islam atau pra-Islam yang tertanam kuat dalam struktur lokal diduga menjadi faktor penting terhadap derajat penerimaan dan pemahaman Islam yang berbeda-beda tersebut. Dengan demikian, pernyataan Schwarz bahwa keberadaan kebanyakan komunitas Islam di Indonesia terdiri atas mereka yang menganggap Islam hanyalah tambahan terakhir dari kantong-kantong tradisi kultural yang campur aduk dapat dibenarkan. ${ }^{11}$

\footnotetext{
${ }^{10}$ Wawancara penulis dengan TGH. Zainal Arifin Munir, 2007.

${ }^{11}$ Adam Schwarz, A Nation in Waiting Indonesian in the 1990, h. 163.
} 
Beragamnya praktik keberagaman umat Islam di Lombok, juga jelas terlihat bahkan dalam lingkup satu komunitas. Dalam satu komuitas kecil kerap dijumpai orang-orang Islam yang saleh dan taat kepada syariah dan rukun Islam, tetapi ada juga Islam nominal yang tidak terlalu ketat menjalankan ritual-ritual Islam, seperti shalat, puasa, membayar zakat, dan naik haji. Bagi kelompok yang disebut kedua, "Islam lebih merupakan persyaratan legal daripada masalah keyakinan religius”. Senada dengan realitas ini, Schwarz mengilustrasikan:

Di sebagian besar tempat, Islam datang di kepulauan Indonesia dengan damai, bukan dengan menaklukkan. Secara umum bisa dikatakan bahwa Islam tidak menggantikan atau menghancurkan tradisi budaya yang sudah lama ada, utamanya Hindu dan Buddha, tetapi disinkretiskan dengan tradisi tadi. Lagi pula para pedagang pembawa Islam yang hampir semuanya menyebarkan ajaran dari mazhab Sufi Islam (Syafii) yang lebih akomodatif terhadap tradisi lokal di banding ajaran Islam ortodoks dari Arab. ${ }^{12}$

Keanekaragaman di antara orang-orang Islam sendiri bukan hanya tampak nyata dalam perpecahan ideologis, tetapi juga dalam praktikpraktik keberagamaan mereka, seperti terlihat pada perpecahan antara golongan Islam modernis dan kelompok Islam tradisionalis atau ortodoks, ${ }^{13}$ baik terjadi di Lombok sebagaimana tergambar di atas maupun di wilayah Indonesia lainnya yang telah banyak diungkap oleh para sarjana, baik di luar maupun dalam negeri.

Secara ringkas, variasi sosial keagamaan masyarakat Sasak dapat digambarkan sebagai berikut:

12 Adam Schwarz, A Nation in Waiting Indonesian in the 1990, h. 165-66.

${ }^{13}$ Menurut Ricklefs bahwa muslim ortodoks adalah mereka yang di luar Alquran dan hadis, mengakui ijma' ulama' dan qiyas. Sebaliknya, muslim modernis hanya mengakui Alquran dan hadis sebagai satu-satunya dasar rujukan, tidak mempergunakan ijma' ulama' dan qiyas. Menurut Ricklefs ijma' ulama' adalah konsensus dari para ahli agama Islam mengenai masalah tertentu yang tidak secara tegas diatur dalam Alquran dan hadis. Qiyas adalah penafsiran Alquran dan hadis yang dilakukan oleh para ahli agama Islam. Lihat M.C Ricklefs, "Six Centuries of Islamzation in Java," t.t. dalam Nehemia Levtzion (ed.), Conversion to Islam (New York: Holmes and Mejer Publisher Inc, 1971), h. 100-128. 
Tabel 5

Variasi Identitas Orang Sasak di Pulau Lombok

\begin{tabular}{|c|c|c|c|}
\hline $\begin{array}{l}\text { Kelompok } \\
\text { Orang Sasak }\end{array}$ & $\begin{array}{l}\text { Orientasi Ideologi/ } \\
\text { Kosmologi }\end{array}$ & $\begin{array}{l}\text { Praktik } \\
\text { Keagamaan }\end{array}$ & $\begin{array}{l}\text { Pemegang } \\
\text { Otoritas }\end{array}$ \\
\hline Boda & $\begin{array}{l}\text { Pantheisme, animisme } \\
\text { dan dewa-dewa lokal }\end{array}$ & $\begin{array}{l}\text { Pemujaan terhadap } \\
\text { kekuatan gaib, } \\
\text { dewa-dewa lokal, } \\
\text { dan roh leluhur }\end{array}$ & $\begin{array}{l}\text { Tetua adat, } \\
\text { pemangku }\end{array}$ \\
\hline Wetu Telu & $\begin{array}{l}\text { Pantheisme, } \\
\text { animisme, dewa-dewa } \\
\text { lokal, adat, dan Islam }\end{array}$ & $\begin{array}{l}\text { Mengagungkan } \\
\text { adat, Islam } \\
\text { sinkretis }\end{array}$ & $\begin{array}{l}\text { Tetua adat, } \\
\text { pemangku, kiai }\end{array}$ \\
\hline $\begin{array}{l}\text { Islam Tarekat } \\
\text { (Naqsabandiah } \\
\text { dan Qadariah) }\end{array}$ & $\begin{array}{l}\text { Alquran, hadis dan } \\
\text { tradisi perguruan }\end{array}$ & $\begin{array}{l}\text { Zikir, pembacaan } \\
\text { mazhab, dan } \\
\text { kesalehan pribadi }\end{array}$ & $\begin{array}{l}\text { Guru tarekat, } \\
\text { kakak } \\
\text { perguruan } \\
\text { senior }\end{array}$ \\
\hline $\begin{array}{l}\text { Islam Tradisional } \\
\text { (NU dan NW) }\end{array}$ & $\begin{array}{l}\text { Alquran, hadis, dan } \\
\text { adat/tradisi setempat }\end{array}$ & $\begin{array}{l}\text { Zikir, pembacaan } \\
\text { mazhab, ziarah ke } \\
\text { tempat keramat } \\
\text { untukm memohon } \\
\text { berkah, dan masih } \\
\text { kukuh pada tradisi }\end{array}$ & $\begin{array}{l}\text { Tuan guru, } \\
\text { dan tokoh } \\
\text { masyarakat } \\
\text { (Pemangku, } \\
\text { kiai, dan tetua } \\
\text { desa) }\end{array}$ \\
\hline $\begin{array}{l}\text { Islam Modernis } \\
\text { (Muhammadiyah } \\
\text { dan Wahabiyah) }\end{array}$ & $\begin{array}{l}\text { Alquran dan hadis } \\
\text { satu-satunya rujukan }\end{array}$ & $\begin{array}{l}\text { Menerapkan } \\
\text { ajaran Islam } \\
\text { secara konsekuen, } \\
\text { tidak bertoleransi } \\
\text { terhadap budaya } \\
\text { setempat }\end{array}$ & $\begin{array}{l}\text { Tuan Guru, } \\
\text { para Jawah, } \\
\text { dan Kiai }\end{array}$ \\
\hline $\begin{array}{l}\text { Perwangsa/ } \\
\text { bangsawan Sasak }\end{array}$ & $\begin{array}{l}\text { Islam dan adat/tradisi } \\
\text { Sasak terutama sorong } \\
\text { serah aji karma }\end{array}$ & $\begin{array}{l}\text { Kukuh } \\
\text { mempertahankan } \\
\text { dan bertoleransi } \\
\text { terhadap budaya } \\
\text { setempat }\end{array}$ & $\begin{array}{l}\text { Sesepuh adat, } \\
\text { tetua desa/ } \\
\text { penglingsir, } \\
\text { pemangku, } \\
\text { pembayun, dan } \\
\text { penemin } \\
\end{array}$ \\
\hline $\begin{array}{l}\text { Jajarkarang/ } \\
\text { orang biasa }\end{array}$ & $\begin{array}{l}\text { Ada sebagian } \\
\text { berorientasi modernis } \\
\text { dan sebagian ke } \\
\text { tradisional }\end{array}$ & $\begin{array}{l}\text { Sebagian kukuh } \\
\text { ingin menghapus } \\
\text { tradisi, dan } \\
\text { sebagian ingin } \\
\text { mempertahankan } \\
\text { tradisi }\end{array}$ & $\begin{array}{l}\text { Tuan guru, } \\
\text { kiai, elite } \\
\text { politik, } \\
\text { birokrat, guru/ } \\
\text { dosen }\end{array}$ \\
\hline
\end{tabular}


Meski demikian, terlepas dari corak keberagamaan yang dilekatkan pada masyarakat Sasak, harus diakui bahwa semangat untuk melaksanakan ajaran Islam sangat tinggi di kalangan umat Islam Sasak. Ini terlihat dari banyaknya sarana peribadatan yang ada, seperti masjid, musholla, dan langgar. Pada tahun 1980-1981 saja tercatat 7.538 buah tempat ibadah dengan rincian 2.402 buah masjid, 1.789 buah mushalla, dan 3.347 buah langgar. ${ }^{14}$

Ajaran agama Islam bagi masyarakat Sasak mendapatkan tempat sangat tinggi dalam menjalankan kehidupan keagamaannya sehari-hari sesuai dengan doktrin yang dianut. Kuatnya tradisi keagamaan Islam ini dapat dilihat dengan jumlah-jumlah tempat ibadah (masjid), sampai sekarang tercatat berjumlah 13.151 buah, untuk itu tidaklah mengherankan bila sekelompok orang menjuluki kepulauan Lombok dengan Pulau Seribu Masjid. Begitu juga dengan fenomena selalu bertambahnya kuota jamaah haji di tiap tahun yang menjadi indikator keseriusan ibadah masyarakat Sasak. ${ }^{15}$

\section{Sekte Minoritas dan Agama Lokal: Kasus Lombok NTB Minoritas Islam Wetu Telu dan Ahmadiyah}

Masuknya Islam di Lombok tidak menjumpai ruang yang vakum. Masyarakat sudah memiliki apa yang disebut budaya. Budaya Lombok bersifat unik dan khas. Budaya inilah yang membedakan orang-orang Sasak dengan orang-orang dan masyarakat daerah lainnya di Indonesia. Mengapa khas?, karen budaya itu dibangun oleh masyarakat untuk kepentingan mereka dalam segala aspek kehidupan. Seperti pernyataan Geertz, mengutip Max Weber, bahwa manusia terikat oleh jaring-jaring yang dipintalnya sendiri. Jaring-jaring itu adalah budaya. Jaring-jaring itu terjalin dari generasi ke generasi (diakronis) sampai pada keadaannya sekarang ini (sinkronis).

Pergumulan Islam dengan khazanah lokal menjadikan Islam begitu multiwajah. Ketika ia menjumpai varian kultur lokal, maka yang segera

${ }^{14}$ Lihat H.L. Wacana, Kebudayaan Sasak, t.t., h. 21.

${ }^{15}$ Muhammad Noor, Muslihan Habib, dan Muhammad Harfin Zuhdi, Visi Kebangsaan, t.t., h. 79 . 
berlangsung ialah aneka proses simbiosis yang saling memperkaya. Demikian di berbagai belahan, halnya juga di Indonesia. Muncullah beragam varian Islam. Ada Islam-Jawa, Islam-Sasak, Islam-Melayu, IslamMadura, Islam-Pesisir, Islam-Poliwali, Islam-Ambon, Islam-Padang, IslamBanjar, Islam-Bima dan seterusnya yang masing-masing mengetengahkan karakter kebenaran yang berbeda. Begitu pula, tak cuma Islam-Arab, tetapi juga Islam-Iran, Islam-Cina, Islam Amerika, Islam India, Islam Indonesia, dan sebagainya yang muncul dengan bangunan kebenaran sendiri-sendiri. ${ }^{16}$

Agama Sasak atau lebih spesifik lagi Islam Sasak merupakan cermin dari pergulatan agama lokal atau tradisional berhadapan dengan agama dunia yang universal dalam hal ini Islam. Seperti yang terjadi di Bayan (Lombok), Islam Wetu Telu (Islam Lokal) yang banyak dipeluk oleh penduduk Sasak asli dianggap sebagai "tata cara keagamaan Islam yang salah (bahkan cenderung syirik)" oleh kalangan Islam Waktu Lima, sebuah varian Islam universal yang dibawa oleh orang-orang dari daerah lain di Lombok. Tak pelak, Islam Waktu Lima sejak awal kehadirannya disengaja untuk melakukan misi atau dakwah Islamiyah terhadap kalangan Wete Telu.

Sebagai kelompok minoritas Islam Wetu Telu, baik secara langsung mapun tidak langsung keberadaannya semakin ditekan oleh tiga lapis "penindasan" sekaligus, yakni arus modernitas, penetrasi aktif dakwah Islamiyah yang tak kunjung surut, dan implikasi massif dari kebijakan politik khususnya program transmigrasi. Mereka yang tersisa kini kian terpencil dari komunitas besar etnis Sasak dan distigma sebagai segmen

${ }^{16}$ Islam lokal yang merupakan hasil integrasi antara universalitas Islam dan lokalitas tradisi selama ini sering dituduh sebagai sejenis Islam yang bernilai rendah, terutama karena ia berbeda dari apa yang biasa dianggap sebagai "genuine" Islam dalam arti Islam Timur Tengah". Seorang muslim dalam kategori itu di kalangan pengkaji Islam disebut dengan istilah nominal muslims. Ada sebuah kata yang sering diucapkan di sini untuk menandai orang-orang Islam yang tidak menjalankan syari'at Islam, yaitu "Islam KTP”. Istilah nominal Islam kurang lebih searti dengan istilah "Islam KTP" tersebut. Istilah nominal muslims berasal dari studi Geerzt tentang Islam di Jawa. Geerz membagi orang (Muslim) Jawa ke dalam tiga kategori dengan keyakinan dan artikulasi keagamaan yang berbeda-beda. Ketiga kategori tersebut adalah santri, abangan dan priyai. Lihat seutuhnya Clifford Geertz, Abangan, Santri, Priyai dalam Masyarakat Jawa, trans. oleh Aswab Mahasin (Jakarta: Pustaka Jaya, 1983). 
masyarakat yang "ketinggalan zaman" dan secara teologis "sesat" dan karenanya perlu didakwahkan.

Benarkah ajaran mereka secara fikih dan teologis sesat? Mengapa selalu termarginalkan nasib keyakinan Islam yang bernuansa lokal? Bukankah ini justeru bukti pluralitas keagamaan dalam Islam sendiri, yang menunjukkan keramahannya terhadap budaya lokal. Padahal beralihnya Orang Sasak dari Boda (sinkretisme Hindu-Budha) menjadi Islam, kemudian dari muslim sinkretis dan nominal-disebut Wetu Telu-menjadi Islam yang sempurna-Waktu Lima-memperlihatkan dinamisme kultural dalam cara Islam disebarkan, kemudian diserap, diakomodasi dan diekspresikan di Indonesia. Dinamisme kultural juga melatari fakta bahwa aktifitas penyebaran dan penanaman ajaran Islam merupakan proses panjang dan berkesinambungan dalam antagonisme dan asimilasi tiada henti. Bukankah dalam wacana fikih terdapat istilah urf, maslahah dan teknik-teknik tambahan lainnya yang mengapresiasi budaya lokal?

Bagi penulis, kasus Islam Wetu Telu adalah masalah pergulatan klaim kebenaran yang biasa terjadi sepanjang sejarah antara kalangan tekstualis, konservatif dan inovatif, Arabis dan kultural, dan antar berbagai varian Islam lain.

\section{Nasib Ahmadiyyah di Lombok}

Ahmadiyah termasuk aliran keagamaan yang paling terakhir datang ke Lombok. Pulau Lombok sebenarnya hanya memiliki beberapa ratus orang Ahmadiyah. Pengusiran dari Bayan, Selong, Praya dan Pancor membuat Ketapang menjadi satu-satunya desa terdapat sejumlah warga Ahmadiyah. Kota Mataram, ibukota provinsi Nusa Tenggara Barat, juga terdapat orang Ahmadiyah namun mereka tinggal menyebar. Warga kota Mataram relatif lebih heterogen. Di Mataram ada banyak orang Hindu Bali maupun orang-orang Kristen Minahasa, Batak, Tionghoa dan lainnya. Pulau Lombok sebelah Barat juga terdapat industri turisme, dengan Pantai Senggigi, hingga daerah ini relatif lebih terbuka daripada desa Sasak yang homogen semacam Ketapang.

Sejarah kelam warga Ahmadiyah dapat dilihat pada 1999 di Bayan, 
Lombok Barat, NTB. Satu orang meninggal dan seorang lagi luka parah karena dibacok. Pada 2001 terjadi lagi peristiwa sama di Pancor, Lombok Timur. Warga Ahmadiyah mengalami penganiayaan dan pengusiran dari tempat tinggalnya. Lebih aneh lagi, Pemda Lombok Timur memberi dua opsi untuk mereka: tetap di Pancor tapi keluar dari Ahmadiyah atau keluar dari Pancor untuk bisa tetap jadi Ahmadiyah. Sungguh ironis di tengah sebuah negara yang, katanya, menjunjung tinggi keberagaman dan hak asasi manusia.

Bagi penulis kasus Ahmadiyah adalah masalah pergulatan klaim kebenaran yang biasa terjadi sepanjang sejarah antara kalangan tekstualis, konservatif dan inovatif, Arabis dan kultural, dan antar berbagai varian Islam lain. Di sini perlunya kritik wacana agama dan pemahaman yang utuh dan tidak tunggal tentang agama.

Salah satu ketidaktunggalan dalam pemahaman agama juga diakibatkan oleh perjumpaan (encounter) berbagai macam tradisi kesejarahan agama melalui praktik antar-agama. Di dunia global ini, sesuatu yang tak dapat dibantah adalah penghuni agama akhirnya mencoba merumuskan konsep moralitas baru. Pertama, masalah moral internal suatu agama yang memiliki legitimasi objektif tentang sisi-sisi keyakinan dirinya terkait dengan hal yang tak dapat dihindari sebagai entitas eksklusif. Kedua, rumusan agama-agama mencari kerangka minimal untuk bergerak secara bersama-sama menghadapi tantangan kegelisahan umat masing-masing. Dan ketiga, membiarkan dengan penuh tanggung jawab pada agama agar berada di kolam besar globalisasi berdasarkan sisi kelenturan dan pluralitasnya. Hal ini tentu sebagai cara memproses sebuah pengujian agama historis, yaitu dapat menyesuaikan dengan hukum sejarah yang menjamin perbedaan. Dengan demikian, tidak terdapat "kesombongan" dalam beragama, sehingga mudah mengkafirkan atau mengklaim mereka sesat, bisa jadi mereka lebih mulia dan lebih Islam di hadapan Tuhan (kufrun indan nass wa lakin mukmin indallah). Pertanggungjawaban seorang umat kepada Tuhannya tidak dapat dirampas oleh orang lain, disamaratakan, atau diklaim karena tidak ada nilai objektif yang dapat dijadikan parameter. Seorang makin beriman atau makin kafir terhadap keyakinannya tidak dapat divonis oleh orang lain. Keduanya memiliki 
karakter yang tidak dapat dipertemukan dalam sebuah ruangan eksekusi. ${ }^{17}$

Nasib jamaah Ahmadiyah di Pulau Lombok, sebenarnya sama dengan perlakuan yang dialami aliran yang berlawanan dengan agama mainstream seperti Islam Wetu Telu. Sekedar informasi, bahwa pola keberagamaan Islam di Lombok sangat variatif termasuk penganut Islam Wetu Telu. Sebagai kelompok minoritas Islam Wetu Telu, baik secara langsung maupun tidak langsung keberadaannya semakin ditekan oleh tiga lapis "penindasan" sekaligus, yakni arus modernitas, penetrasi aktif dakwah Islamiyah yang tak kunjung surut, dan implikasi massif dari kebijakan politik khususnya program transmigrasi. Mereka yang tersisa kini kian terpencil dri komunitas besar etnis Sasak dan distigma sebagai segmen masyarakat yang "ketinggalan zaman" dan secara teologis "sesat" dan karenanya perlu didakwahkan. Benarkah ajaran mereka secara fikih dan teologis sesat? Mengapa selalu termarginalkan nasib keyakinan Islam yang bernuansa lokal? Bukankah ini justeru bukti pluralitas keagamaan dalam Islam sendiri, yang menunjukkan keramahannya terhadap budaya lokal. Padahal beralihnya Orang Sasak dari Boda (sinkretisme Hindu-Budha) menjadi Islam, kemudian dari muslim sinkretis dan nominal -disebut Wetu Telu- menjadi Islam yang sempurna -Waktu Lima- memperlihatkan dinamisme kultural dalam cara Islam disebarkan, kemudian diserap, diakomodasi dan diekspresikan di Indonesia. Dinamisme kultural juga melatari fakta bahwa aktifitas penyebaran dan penanaman ajaran Islam merupakan proses panjang dan berkesinambungan dalam antagonisme dan asimilasi tiada henti.

\section{Tantangan Multikulturalisme di Indonesia}

Dalam penelitian penulis beberapa waktu lalu di pulau Lombok, terdapat kecenderungan narasi eksklusifisme di beberapa golongan dengan melihat pluralitas sebagai hal yang tidak dapat diterima dan golongan yang paling banyak muncul dianggap sebagai golongan Islam yang kebablasan dan wajib diluruskan adalah Islam Liberal dan merupakan musuh Islam

${ }^{17}$ Komaruddin Hidayat, "Agama-agama Besar Dunia: Masalah Perkembangan dan Interaksi," t.t. dalam Komaruddin Hidayat dan Ahmad Gaus AF (ed), Passing Over: Melintasi Batas Agama (Jakarta: PT. Gramedia, 1998), h. 201. 
terbesar dari dalam. Nilai-nilai pluralisme tidak banyak dipahami oleh beberapa kalangan terutama kalangan pemuda sehingga menganggap bahwa selain Islam Sunni (Syi'ah, Ahmadiyah) tergolong Islam yang tidak benar dan tidak dapat diterima di Indonesia.

Sebagian informan menunjukkan bahwa narasi pluralisme agama dan aliran sebagai satu hal yang mengancam dan perlu diwaspadai. Hal ini muncul ketika ditanya perihal Ahmadiyah dan Syi'ah, sebagian besar responden menganggap kedua aliran tersebut sebagai aliran yang menyimpang dan harus disikapi dengan tegas. Beberapa informan yang mengungkapkan bahwa keberadaan Syi'ah dan Ahmadiyah harus dibubarkan lebih banyak ditemukan di kalangan pelajar dan pemuda:

Jannah, salah satu anggota Pemuda Sumbawa di Mataram menuturkan "seperti Ahmadiyah dan Syi'ah itu lebih baik dibubarkan dan setelah dibubarkan diajak atau kita pengaruhi ke jalan yang baik sesuai dengan Islam yang dianut oleh mayoritas masyarakat Indonesia. ${ }^{18}$

Narasi radikal terkait dengan isu ini juga muncul dari Tulus, Ketua Keluarga Mahasiswa Islam Bima (GAMAIS):

Saya sangat sepakat dengan pembubaran jama'ah Ahmadiyah, dan harus disingkirkan dari Indonesia bagaimanapun caranya, silakan membawa nama-nama yang lain apa saja di Indonesia tapi jangan Islam karena dalam Islam tidak ada Nabi setelah Rasulullah. Kalau Syi'ah juga sama saja karena menghina keluarga Rasul. ${ }^{19}$

Bahkan Firmansyah, salah satu pengurus kesatuan Pemuda Bima menanggapinya secara ekstrim:

Jamaah Ahmadiyah tidak banyak tahu, Syi'ah itu aliran agama yang paling kejam adalah Syi'ah yang lain sekali kalimah syahadatnya, dan seorang muslim yang menyebarkan syahadat tersebut dikubur hidup-hidup, maka itu tidak boleh. Ahmadiyah dan Syi'ah itu merusak sunnah-sunnah Rasulullah dan sah untuk dibubarkan. ${ }^{20} \mathrm{Hal}$ sama diungkapkan oleh Riyan, ketua ReMus MAN 2 Mataram bahwa "Syi' ah dan Ahmadiyah sesat dan wajib dibubarkan, karena sudah menyalahi syari'at Islam $^{21}$ begitu pula

\footnotetext{
${ }^{18}$ Jannah (Pemuda Sumbawa), 9 Juli 2013.

${ }^{19}$ Tulus (GAMAIS), 25 Juli 2013.

${ }^{20}$ Firmansyah (Pemuda Bima), 25 Juli 2013.

${ }^{21}$ Riyan (MAN 2 Mataram), 26 Juli 2013.
} 
Brindika, Ketua ReMus SMAN 5 Mataram mengungkapkan bahwa Syiah itu beda tipis dengan Yahudi dan Ahmadiyah itu sesat karena nabinya lain maka harus dibubarkan dan diajak untuk mengikuti kita. ${ }^{22}$

Gugatan terhadap moderatisme dan multikulturalisme melalui kekerasan dilakukan oleh aktor individu, organisasi massa, dan negara, lembaga paling otoritatif yang semestinya berperan sebagai penjamin moderatisme (multikulturalisme) keagamaan dalam bingki keindonesiaan.

Penghakiman terhadap aliran keagamaan baru yang diidentifkasikan melenceng dari arus utama ortodoks telah menjadi tantangan tersendiri bagi entitas Islam yang moderat dan multikultural di Indonesia. Pada tingkat ekstrem, perlawanan tersebut termanifestasi dalam serangkaian aksi intoleran, seperti pengusiran, kekerasan fisik, bahkan pengeboman. ${ }^{23}$

Di sisi lain, di kalangan masyarakat terjadi dan mengalami keterputusan komunikasi antara berbagai pihak. Keterputusan komunikasi itu memaksa berbagai pihak untuk mengembangkan komunikasi yang tidak didukung oleh pengertian yang sama antara mereka. ${ }^{24}$ Oleh sebab itu, perlu dikembangkan sikap komunikasi di lintas kultural.

Untuk lebih memahami multikulturalisme, dan apakah ia merupakan suatu yang ril bergerak di tengah masyarakat, mungkin bisa dimulai dari penelusuran atas peta multikulturalisme itu sendiri. Di sini penulis akan meminjam pemetaan yang dilakukan oleh Bhiku Parekh. Pertama, adalah kelompok masyarakat yang memiliki budaya umumnya masyarakat namun dalam beberapa hal mereka memiliki keyakinan-keyakinan dan praktik-praktik yang berbeda berkaitan dengan perbedaan wilayah-wilayah kehidupan atau mengembangkan cara hidup yang relatif berlainan. Mereka menyerap sistem-sistem makna dan nilai-nilai dominan masyarakat mereka, namun pada saat yang sama, mereka berupaya menciptakan ruang di dalamnya bagi gaya hidup mereka yang berbeda itu. Mereka tak hendak mengajukan suatu budaya alternatif tetapi lebih ingin menganekanya dengan kehadiran mereka tersebut. Bhikhu Parekh menyebut ini ragam

${ }^{22}$ Brindika (SMAN 5 Mataram), 27 Juli 2013.

${ }^{23}$ Masdar Hilmy, Jalan Demokrasi Kita, Etika Politik, Rasionalitas dan Kesalehan Publik, 99.

${ }^{24}$ Zuhairi Misrawi, Alquran Kitab Toleransi, Inklusivisme, Pluralisme dan Multikulturalisme (Jakarta: P3M, 2007). 
subkultur (subcultural diversity). Mereka yang termasuk dalam kelompok ragam subkultur ini adalah kalangan waria, anak-anak jalanan, orang tua tunggal, guy, lesbi, dan berbagai individu atau kelompok yang mengikuti gaya hidup atau struktur keluarga yang tidak konvensional.

Kedua, anggota atau kalangan masyarakat yang sangat kritis terhadap beberapa prinsip atau nilai utama dari budaya dominan yang ada di dalam masyarakat dan berupaya untuk membentuknya kembali. Contoh untuk ini adalah kalangan feminis yang terus menyerang bias patriaki yang demikian berurat berakar dalam masyarakat, kalangan agama yang tak henti mengeluhkan orientasi sekular pemerintahan, dan kalangan pecinta lingkungan yang terus mengkritik bias antroposentris dan teknoratik dalam pengelolaan sumber daya alam. Berdasarkan pandangan yang berlawanan ini, mereka berupaya mengubah budaya dominan tersebut dan membentuknya sesuai dengan pandangan mereka. Bhikhu Parekh menyebut keanekaan ini sebagai ragam pandangan (perspectival diversity).

Ketiga, adalah komunitas-komunitas yang memiliki kesadaran diri dan terorganisasi dengan cukup baik yang memiliki dan hidup dengan sistem-sistem keyakinan dan praktiknya sendiri yang berbeda. Termasuk dalam kalangan ini adalah para imigran/pendatang, berbagai komunitas keagamaan, dan kelompok-kelompok budaya yang terkonsentrasi secara teritorial seperti orang-orang asli (indigenous peoples). Parekh menyebut ini sebagai ragam komunal (communal diversity). ${ }^{25}$

\section{Strategi Meneguhkan Nilai Multikulturalisme}

\section{Re-interpretasi Pemahaman Keagamaan}

Dalam upaya membangun hubungan sinergi anatara multikulturalisme dan agama, minimal diperlukan dua hal. Pertama, penafsiran ulang atas doktrin-doktrin keagamaan ortodoks yang sementara ini dijadikan dalih untuk bersikap eksklusif dan opresif. Penafsiran ulang itu harus dilakukan sedemikan rupa sehingga agama bukan saja bersikap reseptif terhadap

${ }^{25}$ Hairus Salim HS dan Suhadi, Membangun Pluralisme dari Bawah (Yogyakarta: LKiS, 2007), 104. Juga Bhikhu Pareh, Rethinking Multiculturalism, Keragaman Budaya dan Teori Politik, trans. oleh IMPULSE (Yogyakarta: Kanisius, 2008), h. 21-22. 
kearifan tradisi lokal, melainkan juga memadu di garda depan untuk mengantarkan demokrasi built-in dalam masyarakat-masyarakat beragama.

Kedua, mendialogkan agama dengan gagasan-gagasan modern. Saat ini, umat beragama memasuki suatu fase sejarah baru di mana mereka harus mampu beradaptasi dengan peradaban-peradaban besar yang tidak didasarkan pada agama, seperti kultur barat modern. Bangsa Indonesia tentu tidak mungkin menghindar dari ide-ide dan teori-teori sekuler. Itu berarti, menyentuh istilah-istilah dengan gagasan non-relegius itu merupakan tugas yang paling menantang yang dihadapi kaum muslim pada zaman modern ini.

Abdolkarim Sorous, intelektual muslim asal Iran, menegaskan bahwa umat beragama dihadapkan pada dua persoalan: local problems (problemproblem lokal) dan universal problem (problem-problem universal) yakni problem kemanusiaan secara keseluruhan. Menurutnya, saat ini problem-problem seperti kedamaian, hak-hak asasi manusia, hak-hak perempuan, telah menjadi problem global dan harus diselesaikan pada level itu. Hanya dengan transformasi internal dan interaksi dengan gagasan-gagasan modern, agama akan mampu melakukan reformulasi sintesis kreatif terhadap tuntutan multikulturalisme yang telah menjadi semangat zaman. ${ }^{26}$

\section{Dekonstruksi Hukum Islam menuju Fikih Pluralisme}

Ide dekonstruksi yang diadopsi oleh para pemikir Islam ini dimaksudkan untuk memisahkan secara dikotomik hubungan antara dimensi historisitas yang aturannya selalu berubah-ubah, dengan normativitas Alquran atau keagamaan Islam, yang sesuai dengan waktu dan tempat. Ide ini dimaksudkan juga untuk melelehkan kalau tidak menghancurkan pemikiran keagamaan yang olehnya dianggap telah disakralkan oleh umat Islam (taqdîs al-afkâr al-dîniy), termasuk dalam bidang fikih yang terkungkung dalam jebakan otoritarianisme para ulama klasik sehingga menjadi ortodoksi baru.

Maka bagi pemikir Islam kontemporer, prioritas pertama yang harus

${ }^{26}$ Hairus Salim HS dan Suhadi, Membangun Pluralisme dari Bawah, h. 119. 
dibongkar adalah pelapisan geologi pemikiran Islam yang ter (di) bentuk secara historis, berlapis-lapis dan berlangsung lama, Arkoun menyebutnya sebagai “ortodoksi." Sebab seperti yang dianggapnya, tradisi keislaman yang tercermin dalam konsep ortodoksi ini, seperti teologi, gnostik (tasawuf) dan fikih tidak lain adalah merupakan hasil rumusan manusia biasa, yang tidak luput dari kepentingan dan intervensi "ideologi” tertentu yang berkembang pada saat itu, meskipun dibingkai dengan berbagai petikan wahyu atau hadis Nabi Muhammad. Kalau gugusan yang mewarnai corak dan bentuk serta isi tradisi keilmuan Islam itu benar terhegemoni, katanya, maka tradisi itu sah saja untuk dikritisi, didekonstruksi, dibahas dan dianalisis, supaya menghasilkan tradisi yang terbuka dan pluralis yang benar-benar asli dan bebas dari bias-bias kepentingan, terlebih-lebih pengaruh dari ortodoksi.

Fikih atau hukum Islam yang berkembang selama ini telah menjadi ortodoksi baru akibat pensakralan yang berlebihan dari para pengagumnya. Para pemberi fatwa dalam hukum Islam tidak lagi memikirkan hukum Tuhan tetapi telah berbicara atas nama Tuhan atau menjadi juru bicara Tuhan. Hukum Islam yang merupakan produk pemikiran abad ke 2 Hijrah sangat sarat dengan prior text atau lingkungan yang mengitarinya. ${ }^{27}$

Persoalan ini memang cukup mendasar. Pertama, dikarenakan fikih sengaja ditulis dalam masa yang mana hubungan antara muslim dan nonmuslim tidak begitu kondusif. Nasir Hamid Abu Zyaid menyebutkan, bahwa kitab-kitab klasik ditulis dalam sebuah zaman yang mana umat Islam sedang menghadapi perang salib, sehingga diperlukan upaya strategis untuk mempertahankan identitas dan mengembalikan epistemologi Islam dalam kerangka "teks". Fikih merupakan bagian terpenting dari proses pergulatan kehidupan pada saat itu, sehingga sangat besar kemungkinan bila fikih menyesuaikan diri dengan konteks zamannya.

${ }^{27}$ Prior Text adalah latar belakang, persepsi, dan keadaan individu penafir, yakni bahasa dan konteks kultural di mana teks tersebut ditafsirkan. Inilah yang mampu memperluas perspektif dan kesimpulan penafsiran, sekaligus menunjukkan individualitas tafsiran. Hal ini tidak bisa dikatakan baik, namun juga tidak bisa disebut buruk bagi tafsir tersebut. Tetapi penting dipahami secara kritis agar menemukan konteks yang sebenarnya. Karena menurutnya: No Method of Qur'anic exegesis fully objective. Each exegete makes some subjective choices". Baca Amina Wadud Muhsin, Perempuan di dalam Alquran, trans. oleh Yaziar Radianti (Bandung: Pustaka, 1994), h. 7-8. 
Kedua, fikih ditulis dalam situasi internal umat Islam yang tidak begitu solid, sehingga amat dimungkinkan para penguasa menggunakan fikih sebagai salah satu alat untuk mengambil hati masyarakat, sehingga para ulamanya dapat mendesain fikih seolah-olah memberikan perhatian kepada umat Islam dan menolak kehadiran non-Islam. Cara pandang seperti ini dapat memikat umat Islam, dikarenakan sikap bangsa-bangsa non-muslim terhadap Islam yang cenderung hegemonik dan kolonialistik.

Ketiga, adanya simbol keagamaan yang secara implisit menganjurkan sikap keras terhadap agama lain. Dalam banyak ayat, terutama bila dibaca secara harfiah, maka akan disimpulkan secara rigid dan kaku. ${ }^{28}$

Problem-problem yang menjadi dilematisme fikih lintas agama ini telah mengakibatkan hubungan yang tidak baik antara muslim dan nonmuslim, dan pada tahap selanjutnya fikihpun terbawa arus besar cara pandang masyarakat muslim. Ada beberapa konsep dalam doktrin fikih klasik yang mengakibatkan dilametisme fikih lintas agama seperti konsep ahl al-dzimmah, jizyah, kawin beda agama dan waris beda agama. ${ }^{29}$

Dalam konteks ini sangat terlihat adanya kegagapan fikih dalam melihat agama lain. Di sini terlihat betapa pentingnya melihat fikih secara kritis. Memaksakan diri untuk menggunakan kesimpulan-kesimpulan yang digunakan ulama klasik dalam merespon masalah kekinian dianggap upaya mengorbankan masa kini untuk masa lalu. Bila yang terjadi demikian, maka agama akan dituduh sebagai ajaran yang tidak kontekstual. Agama akan dituduh sebagai biang dari kemunduran, kebodohan, ketidakadilan dan kezaliman.

Diperlukan sekarang yaitu mengembalikan nilai-nilai universal seperti kemaslahatan umum, egaliterianisme, rasionalisme, pluralisme sebagai prinsip-prinsip paradigmatik fikih sehingga tidak terjebak dalam kubangan litreralisme, fundamentalisme, otoritarianisme dan

${ }^{28}$ Nurcholish Madjid, dkk, Fiqih Lintas Agama (Jakarta: Paramadina, 2004), h. 43-44.

${ }^{29}$ Khusus untuk masalah perkawinan antaragama memang sangat kontroversial dan belum ada kata final pada satu kesimpulan, antara yang membolehkan dan melarang mempunyai argumen yang sama-sama otoritatif. Walaupun sering ada himbauan larangan untuk melakukan perkawinan antaragama namun dalam praksisnya sulit dihindari, apalagi belakangan ini Paramadina sudah menjadi fasilitator untuk perkawinan beda agama, sebuah terobosan baru dalam wacana fikih Islam di Indonesia. Respon pro-kontrapun mengiringi terobosan ini. 
konservatisme. Selain itu, dekonstruksi pemikiran keagamaan di masa datang mesti mengembangkan budaya tafsir yang terbuka dan toleran. Di sini hermeneutika dapat dijadikan mekanisme mengungkap "makna yang tertunda" guna mengembalikan komitmen wahyu yang bersifat universal dan pluralis. Hermeneutika dimaksud tidak hanya sekedar "revelasionis" yang menggantung diri pada wahyu yang terbatas pada teks, akan tetapi lebih diaplikasikan dalam hermeneutika "fungsional", yaitu sejauh mana teks mampu melakukan pembebasan terhadap realitas kemanusiaan.

Oleh sebab itu, dalam menajamkan komitmen toleransi dan pluralisme fikih, diperlukan hermeneutika, setidaknya bisa melakukan perubahan yang sangat mendasar dalam tradisi fikih klasik. Pertama, mengimani teks sebagai produk budaya. Teks dan budaya adalah dua mata uang logam yang tidak bisa dipisahkan. Ketika berbicara teks sesungguhnya berbicara budaya, begitu juga sebaliknya. Karenanya diperlukan dekonstruksi keyakinan teologis dari eksistensi teks sebagai wahyu Tuhan, menjadi wahyu yang dibentuk dan disempurnakan oleh budaya. Kedua, mengimani teks sebagai wahyu progresif, sehingga tidak menjadi ideologis dan dijadikan alat justifikasi kekuasaan politik. Apabila terdapat pertentangan antara teks dengan problem kemanusiaan, maka dengan sendirinya teks tidak dapat digunakan. Ketiga, mengimani adanya paradigma emansipatoris yang sejalan dengan komitmen wahyu, seperti Alquran sebagai teks terbuka, kesetaraan, kemanusiaan, pluralisme, pembebasan, kesetaraan, keadilan jender, dan tidak diskriminatif. ${ }^{30}$

\section{Menggagas Fikih Multikuluralisme dalam Bernegara}

Multikulturalisme merupakan pengakuan bahwa beberapa kultur lokal yang berbeda dapat eksis dalam lingkungan yang sama dan menguntungkan satu sama lain, atau pengakuan dan promosi terhadap pluralisme kultural.

Sebagai institusi pembebas, fikih harus dimaknai proses bukan produk monumental. Hukum Islam atau fikih, memiliki karakteristik yang jauh berbeda dengan hukum dalam pengertian ilmu hukum modern. Hukum Islam dikembangkan berdasarkan wahyu di samping pemikiran

${ }^{30}$ Nurcholish Madjid, dkk, Fiqih Lintas Agama, h. 174-75. 
manusia, yang memuat aspek lokalitas kultural dan universalitas. Dengan demikian, fikih dikatakan sebagai hasil akhir dari suatu proses dialogis dan dialektis antara pesan-pesan samawi (normativitas) dengan kondisi aktual bumi (historisitas). Aturan-aturan yang terbukukan dalam berbagai kitab fikih tidak dapat dilepaskan dari pengaruh cara pandang manusia, baik secara pribadi maupun sosial. Dengan demikian, selain sarat dengan nilai teologis, fikih juga memiliki watak sosiologis. ${ }^{31}$

Dengan penjelasan di atas, fikih berarti dapat membentuk dan dibentuk oleh masyarakat. Hubungan yang saling mengisi ini menunjukkan betapa dominan muatan kultural dalam fikih itu. Kuatnya muatan kultural itu dapat dibuktikan dengan keterbukaan fikih untuk menerima konsep 'urf, istihssân serta istislâh sebagai bagian dari sumber-sumber fikih. ${ }^{32}$ Ada beberapa bukti kesejarahan lainnya untuk menunjukkan bagaimana kondisi sosial budaya memberikan pengaruh kuat terhadap pembentukan fikih. Adanya qaul jadîd dari Imam Syâfi'i yang dikompilasikan setelah sampainya ia di Mesir, ketika dikontraskan dengan qaul qadîm-nya yang dikompilasikan di Irak, merefleksikan adanya pengaruh dari tradisi adat kedua negeri yang berbeda. Imam Mâlik percaya bahwa aturan adat dari suatu negeri harus dipertimbangkan dalam memformulasikan suatu ketetapan, walaupun ia memandang adat ahl al-Madînah sebagai variabel yang paling otoritatif dalam teori hukumnya, merupakan bukti lain dari kuatnya pengaruh kultur setempat tidak pernah dikesampingkan oleh para juris muslim dalam usahanya untuk membangun hukum. ${ }^{33}$

${ }^{31}$ Masnun Tahir, "Paradigma Pemikiran Reaktualisasi Hukum Islam di Indonesia: Sebuah Telaah Historis Politis," Jurnal Istinbath IAIN Mataram, (Juni 2004): h. 65-67.

${ }^{32}$ Karena secara sosiologis dan kultural, hukum Islam adalah hukum yang mengalir dan berurat berakar pada budaya masyarakat. Hal tersebut disebabkan karena fleksibelitas dan elastisitas yang dimiliki hukum Islam. Artinya, kendatipun hukum Islam tergolong hukum yang otonomkarena adanya otoritas Tuhan di dalamnya — akan tetapi dalam tataran implementasinya ia sangat aplicable dan acceptable dengan berbagai jenis budaya lokal. Karena itu, bisa dipahami bila dalam sejarahnya di sebagian daerah ia mampu menjadi kekuatan moral masyarakat (moral force of people) dalam berdialektika dengan realitas kehidupan. Baca Marzuki Wahid dan Rumadi, Figh Madzhab Negara (Yogyakarta: LKiS, 2001), h. 81.

${ }^{33}$ Ratno Lukito, Pergumulan Antara Hukum Islam dan Adat di Indonesia (Jakarta: INIS, 1998), h. 19. Lihat juga, Masnun Tahir, "Pergumulan Hukum Islam dan Budaya Sasak," Istqira, Jurnal Penelitian Direktorat Perguruan Tinggi Agama Islam, DEPAG RI 06, no. 1 (2007): h. 173-75. 
Fenomena yang disebut terakhir ini menunjukkan bahwa fikih Islam adalah hukum yang hidup dan berkembang, mampu bergumul dengan persoalan-persoalan lokal yang senantiasa meminta etik dan paradigma baru. Keluasan hukum Islam adalah satu bukti dari adanya ruang gerak dinamis itu. Ia merupakan implementasi obyektif dari doktrin Islam yang meskipun berdiri di atas kebenaran mutlak dan kokoh, juga memiliki ruang gerak dinamis bagi perkembangan, pembaharuan dan kehidupan sesuai dengan fleksibilitas ruang dan waktu.

Begitu juga bagi orang yang mempelajari berbagai ikhtilâf, 34 ketegangan bahkan konflik, yang muncul mengiringi lahirnya mazhabmazhab fikih, akan tahu bahwa semua itu merujuk pada perbedaan tempat, waktu, situasi dan sosial budaya di mana hukum itu tumbuh.

Dari uraian tersebut, fikih yang berwawasan multikultural memiliki arti penting karena masyarakat/bangsa Indonesia terdiri dari berbagai golongan yang berbeda secara etnis, sosial, politis, ekonomis, keagamaan, dan kultural. Masyarakat yang seperti ini memerlukan ketentuan fikih yang akomodatif dan apresiatif terhadap keragaman tersebut. Karena itu, identitas hukum fikih dapat diperluas berdasarkan keragaman identitas yang berkembang di masyarakat. Sebab, identitas yang diharapkan bukanlah identitas yang statis tetapi identitas yang dinamis. Keragaman yang ada yang berlandaskan identitas keagamaan itu diharapkan oleh paradigma ushîl fiqh multikultural ini akan bersinergi, sehingga keberagaman identitas tidak berjalan sendiri-sendiri, tetapi keragaman identitas baik budaya, agama, maupun kultur sama-sama semakin diperluas dan diperkaya.

${ }^{34}$ Perbedaan pendapat dalam memutuskan hukum Islam di antara ulama fiqh (ikhtilâf al-fuqahâ) merupakan kebiasaan sejak masa awal. Bahkan, ketika Nabi Muhammad Saw. masih hidup, perbedaan telah terjadi, yaitu ketika sahabat Nabi terjadi perbedaan dalam memahami perintah Nabi atau dalam memahami teks Alquran. Nabi dalam beberapa hal membiarkannya. Dalam perkembangan selanjutnya, maka ikhtilâf ini menjadi inherent dengan hukum Islam, sehingga lahirlah adagium "siapa yang tidak mengetahui ikhtilaf, maka dia tidak akan banyak mengetahui fikih". Lihat N.J. Coulson, Conflict and Tension in Islamic Yurisprudence (Chicago: The University of Chicago Press, 1969), h. 21. 


\section{Membumikan Nilai Pluralisme dan Multikulturalisme Berbasis Kearifan Lokal}

Kemajemukan yang dimiliki bangsa Indonesia adalah sebuah kekayaan dan karunia besar serta merupakan karya Tuhan. Nenek moyang bangsa Indonesia sudah mewariskan dari generasi ke generasi nilai-nilai toleransi, solidaritas dan kesetaraan. Dari sisi kultural Indonesia mewarisi kearifan lokal yang sarat dengan nilai-nilai pluralisme. Tantangannya adalah bagaimana agar nilai-nilai kearifan lokal itu harus mengakar dalam sistem demokrasi dan budaya masyarakat Indonesia. Namun sebagai catatan berdasarkan refleksi kritis, diskursus yang berkembang dan observasi yang penulis lakukan di berbagai lokasi termasuk di Lombok, ada beberapa strategi yang harus dilakukan:

a. Perlunya perhatian mengenai posisi para penganut agama-agama di luar 6 (enam) agama resmi di Indonesia (Islam, Kristen, Katolik, Hindu, Budha dan Konghucu). Para penganut agama di luar 6 (enam) agama tersebut juga ingin diakomodasi dalam asas dan prinsip kewarganegaraan di negeri ini. Hal ini menguat dalam perbincangan perlu tidaknya status mereka muncul secara eksplisit di KTP.

b. Negara harus menyikapi munculnya semakin banyak gerakan keagamaan dan spiritualitas baru yang semakin lama semakin menunjukkan grafik peningkatan. Bukannya pada masa lalu tidak ada gerakan serupa, tetapi gerakan-gerakan semacam ini tidak berani menunjukkan identitas keagamaan yang asli karena takut sanksi hukum dari rezim negara yang relatif tidak seterbuka sekarang.

c. Pendirian rumah ibadah mestinya tidak perlu memunculkan keresahan di kalangan umat beragama jika terdapat kematangan beragama pada masing-masing umat beragama.

d. Kekerasan antar umat beragama, terutama terhadap kelompok minoritas (Syi'ah, Ahmadiyyah dan agama lokal).

e. Penafsiran keagamaan yang sempit, literal dan konservatif mengancam keberadaan kelompok keagamaan yang memiliki tafsir berbeda. Tafsir sempit telah membutakan para penganutnya dalam melakukan takfîri dan bisa berujung pada aksi-aksi kekerasan 
kepada kelompok tafsir yang berbeda. ${ }^{35}$

Nilai multikulturalisme ala Indonesia adalah tidak menganakemaskan minoritas, tetapi tidak juga mengistimewakan mayoritas. Multikulturalisme Indonesia juga harus menekankan kebebesan dan tanggungjawab sekaligus. Multikulturalisme Indonesia dapat mengembangkan istilah-istilah seperti kemajemukan budaya, berbeda tetapi tetap satu, Indonesia kosmopolitan, satu negeri banyak budaya dan agama, dan semacamnya.

Multikulturalisme Indonesia juga harus menggambarkan keaktifan dan proaktif dalam menghadapi tantangan-tantangan dan peluangpeluaang yang diakibatkan kemajemukan tersebut. Ini berarti sikap dan kebijakan yang mengakui dan menghargai kemajemukan budaya Indonesia. Ia menerima dan menghargai hak semua warga Indonesia untuk mengungkapkan dan membagi warisan budaya individual dalam kerangka komitmen, serta struktur-struktur dan nilai demokrasi Indonesia.

\section{Penutup}

Sejak awal perkembangan Islam sebagai konsepsi realitas telah menerima akomodasi sosio-kultural. Akomodasi ini semakin terlihat ketika wilayah Islam berkembang sedemikian rupa sehingga ia menjadi agama yang mendunia. Pada kasus-kasus tertentu, akomodasi itu tercipta sedemikian rupa, sehingga memunculkan "varian Islam". Ajaran normatif dan sejarah Islam yang sangat terbuka dan mengapresiasi tradisi lokal kiranya bisa menjadi modal bagi umat Islam dalam memasuki era multikulturalisme. Setiap manusia, apa dan bagaimanapun tradisinya, menempati posisi sejajar yang patut dihargai dan diakui keberadaannya. Oleh karenanya, bagi Islam, multikulturalisme malah menjadi celah dalam upaya mewujudkan visi Islam yang rahmatan lil álamin.

Masyarakat yang majemuk (plural) di mana penduduk dari pelbagai latar belakang etnik, suku, bangsa dan agama berkumpul dan hidup bersama akan menimbulkan tantangan-tantangan tersendiri yang perlu dijawab oleh masyarakat perkotaan dengan mengembangkan sifat-sifat yang

${ }^{35}$ Lukman Hakim Saifuddin, "Sambutan dalam Acara AICIS XIV, Kerjasama Direktorat Jenderal Pendidikan Islam Kemenag RI, dengan STAIN Samarinda, 21 November 2014, h. x. 
cocok dengan keadaan. Sifat-sifat yang cocok dengan keadaan masyarakat kota inilah yang dimaksud dengan masyarakat madani-multikultural dan tentu saja melibatkan sikap-sikap tertentu yang menjadi tuntutan masyarakat multikultural. Sikap-sikap tersebut antara lain meliputi inklusivisme, humanisme/egalitarianisme, toleransi, dan demokrasi.

\section{Pustaka Acuan}

Ali, Muhamad. Teologi Pluralis-Mutikulturalis, Menghargai Kemajemukan Menjalin Kebersamaan. Jakarta: Kompas, 2003.

Amirin, Tatang M. "Implementasi Pendekatan Pendidikan Multikultural Kontekstual Berbasis Kearifan Lokal di Indonesia." Jurnal Pembangunan Pendidikan: Fondasi dan Aplikasi 1, no. 1 (2012).

Ambarwangi, Sri, dan S. Suharto. "Pendidikan Multikultural di Sekolah Melalui Pendidikan Seni Tradisi." Harmonia: Journal Of Arts Research And Education 13, no. 1 (2013).

Budiwanti, Erni. Islam Sasak; Wetu Telu Versus Waktu Lima. Yogyakarta: LKiS, 2000.

Coulson, N.J. Conflict and Tension in Islamic Yurisprudence. Chicago: The University of Chicago Press, 1969.

Cholil, Suhadi. Resonansi Dialog Agama dan Budaya: dari Kebebasan Beragama, Pendidikan Multikultural, sampai RUU Anti Pornografi. Center for Religious \& Cross-Cultural Studies, Sekolah Pascasarjana, Universitas Gadjah Mada, 2008.

Dijk, V.C. Rebellion Under the Banner of Islam. The Hague: Martinus Nijhoff, 1981.

Geertz, Clifford. Abangan, Santri, Priyai dalam Masyarakat Jawa, trans. oleh Aswab Mahasin. Jakarta: Pustaka Jaya, 1983.

Gunawan, Ketut, Dan Yohanes Rante. "Manajemen Konflik Atasi Dampak Masyarakat Multikultural di Indonesia." Jurnal Mitra Ekonomi dan Manajemen Bisnis 2, No. 2 (2011): 212-224.

Hilmy, Masdar. Jalan Demokrasi Kita, Etika Politik, Rasionalitas dan Kesalehan Publik. Malang: Intrans Publishing Malang, 2017. 
Hidayat, Komaruddin. "Agama-agama Besar Dunia: Masalah Perkembangan dan Interaksi," t.t. dalam Komaruddin Hidayat dan Ahmad Gaus AF (ed), Passing Over: Melintasi Batas Agama. Jakarta: PT. Gramedia, 1998.

HS, Hairus Salim dan Suhadi, Membangun Pluralisme dari Bawah. Yogyakarta: LKiS, 2007.

Ibrahim, Ruslan. "Pendidikan Multikultural: Upaya Meminimalisir Konflik dalam Era Pluralitas Agama.” El Tarbawi 1, no. 1 (2008): 115-127.

Kusmaryani, Rosita Endang. "Pendidikan Multikultural Sebagai Alternatif Penanaman Nilai Moral Dalam Keberagaman.” Paradigma 1, No. 02 (2011).

Lukito, Ratno. Pergumulan Antara Hukum Islam dan Adat di Indonesia. Jakarta: INIS, 1998.

Lestari, Gina. "Bhinnekha Tunggal Ika: Khasanah Multikultural Indonesia di Tengah Kehidupan Sara." Jurnal Ilmiah Pendidikan Pancasila dan Kewarganegaraan 28, No. 1 (2016).

Muhsin, Amina Wadud. Perempuan di dalam Alquran, trans. oleh Yaziar Radianti. Bandung: Pustaka, 1994.

Madjid, Nurcholish, dkk. Fiqih Lintas Agama. Jakarta: Paramadina, 2004. Mania, Sitti. "Implementasi Pendidikan Multikultural dalam Pembelajaran." Lentera Pendidikan: Jurnal Ilmu Tarbiyah dan Keguruan 13, No. 1 (2010): 78-91.

Ma’arif, Syamsul. "Transformative Learning dalam Membangun Pesantren Berbasis Multikultural." Jurnal Pembangunan Pendidikan: Fondasi dan Aplikasi 1, No. 1 (2012).

Misrawi, Zuhairi. Alquran Kitab Toleransi, Inklusivisme, Pluralisme dan Multikulturalisme. Jakarta: P3M, 2007.

Muqoyyidin, Andik Wahyun. "Membangun Kesadaran InklusifMultikultural untuk Deradikalisasi Pendidikan Islam.” Jurnal Pendidikan Islam 2, no. 1 (2012).

Noor, Muhammad, Muslihan Habib, dan Muhammad Harfin Zuhdi, Visi Kebangsaan, t.t. 
Wahid, Marzuki dan Rumadi, Fiqh Madzhab Negara. Yogyakarta: Lkis, 2001.

Zuriah, Nurul. "Model Pengembangan Pendidikan Kewarganegaraan Multikultural Berbasis Kearifan Lokal dalam Fenomena Sosial Pasca Reformasi di Perguruan Tinggi." Jurnal Penelitian Pendidikan 12, No. 2 (2011): 63-72.

Zainiyati, Husniyatus Salamah. "Pendidikan Multikultural: Upaya Membangun Keberagamaan Inklusif di Sekolah." Islamica: Jurnal Studi Keislaman 1, No. 2 (2007): 135-145.

Nurjaya, I. Nyoman. "Pembangunan Hukum Negara dalam Masyarakat Multikultural: Perspektif Hukum Progresif.” Progressive Law Journal (Jurnal Hukum Progresif) 3, no. 2 (2011): 16..

Pareh, Bhikhu. Rethinking Multiculturalism, Keragaman Budaya dan Teori Politik. trans. oleh IMPULSE. Yogyakarta: Kanisius, 2008.

Ricklefs, M.C. "Six Centuries of Islamzation in Java," t.t. dalam Nehemia Levtzion (ed.), Conversion to Islam. New York: Holmes and Mejer Publisher Inc, 1971.

Ricklefs, M.C. Sejarah Indonesia Modern. Yogyakarta: Gadjah Mada University Press, 1991.

Saifuddin, Lukman Hakim, "Sambutan dalam Acara AICIS XIV, Kerjasama Direktorat Jenderal Pendidikan Islam Kemenag RI, dengan STAIN Samarinda, 21 November 2014, h. x.

Schwarz, Adam. A Nation in Waiting Indonesian in the 1990. Australia: Allen \& Unwin Pty Ltd, 1994

Sodli, Ahmad "Revitalisasi Kearifan Lokal dalam Masyarakat Multikultural di Kecamatan Lingsar, Lombok Barat, NTB”, Jurnal Analisa 17, no. 2, (2010).

Suparlan, Parsudi. "Menuju Masyarakat Indonesia yang Multikultural." Antropologi Indonesia (2014).

Susanto, Edi Susanto Edi. "Pendidikan Agama Berbasis Multikultural (Upaya Strategis Menghindari Radikalisme)." Jurnal Karsa (Terakreditasi No. 80/Dikti/Kep/2012) 9, No. 1 (2012): 782-789.

Syahrir, Sultan "Mulitkulturalisme: Perspektif Normatif dan Historis", Jurnal Analisis 13, no. 2, (2013). 
Tahir, Masnun. "Pergumulan Hukum Islam dan Budaya Sasak," Istqira, Jurnal Penelitian Direktorat Perguruan Tinggi Agama Islam, DEPAG RI 06, no. 1 (2007): 173-75.

, "Paradigma Pemikiran Reaktualisasi Hukum Islam di Indonesia: Sebuah Telaah Historis Politis," Jurnal Istinbath IAIN Mataram, (Juni 2004), 65-67.

\section{Wawancara}

Jannah (Pemuda Sumbawa), 9 Juli 2013

Tulus (GAMAIS), 25 Juli 2013.

Firmansyah (Pemuda Bima), 25 Juli 2013.

Riyan (MAN 2 Mataram), 26 Juli 2013.

Brindika (SMAN 5 Mataram), 27 Juli 2013.

TGH. Zainal Arifin Munir, 2007. 